\title{
Erratum: Sociotropic personality traits positively correlate with the severity of social anxiety
}

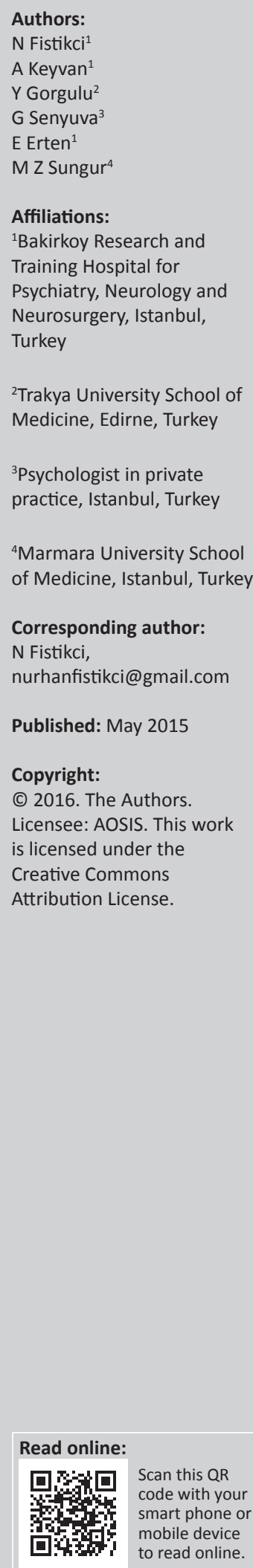

This article was erroneously published in 2015 under the DOI citation S Afr J Psychiatr 2015;22(2) instead of the correct S Afr J Psychiatr 2015;21(2). 